\title{
Article \\ Combustion Processed Nickel Oxide and Zinc Doped Nickel Oxide Thin Films as a Hole Transport Layer for Perovskite Solar Cells
}

\author{
Ponmudi Selvan Thiruchelvan ${ }^{1}\left(\mathbb{D}\right.$, Chien-Chih Lai ${ }^{1,2}(\mathbb{D})$ and Chih-Hung Tsai ${ }^{2, *}$ \\ 1 Department of Physics, National Dong Hwa University, Hualien 97401, Taiwan; \\ lonelyselva@gmail.com (P.S.T.); cclai@gms.ndhu.edu.tw (C.-C.L.) \\ 2 Department of Opto-Electronic Engineering, National Dong Hwa University, Hualien 97401, Taiwan \\ * Correspondence: cht@mail.ndhu.edu.tw; Tel.: +886-3-890-3199
}

\section{check for} updates

Citation: Thiruchelvan, P.S.; Lai, C.-C.; Tsai, C.-H. Combustion

Processed Nickel Oxide and Zinc

Doped Nickel Oxide Thin Films as a Hole Transport Layer for Perovskite Solar Cells. Coatings 2021, 11, 627. https: / / doi.org/10.3390/ coatings11060627

Academic Editors: Lucia Nicoleta Leonat and Philipp Vladimirovich Kiryukhantsev-Korneev

Received: 1 April 2021

Accepted: 22 May 2021

Published: 24 May 2021

Publisher's Note: MDPI stays neutral with regard to jurisdictional claims in published maps and institutional affiliations.

Copyright: (c) 2021 by the authors. Licensee MDPI, Basel, Switzerland. This article is an open access article distributed under the terms and conditions of the Creative Commons Attribution (CC BY) license (https:// creativecommons.org/licenses/by/ $4.0 /)$.

\begin{abstract}
Combustion processed nickel oxide $\left(\mathrm{NiO}_{x}\right)$ thin film is considered as an alternative to the sol-gel processed hole transport layer for perovskite solar cells (PSCs). In this paper, $\mathrm{NiO}_{x}$ thin film was prepared by the solution-combustion process at $250{ }^{\circ} \mathrm{C}$, a temperature lower than the actual reaction temperature. Furthermore, the properties of the $\mathrm{NiO}_{x}$ hole transport layer (HTL) in PSCs were enhanced by the incorporation of zinc $(\mathrm{Zn})$ in $\mathrm{NiO}_{x}$ thin films. X-ray diffraction and X-ray photoelectron spectroscopy results revealed that the formation of $\mathrm{NiO}_{x}$ was achieved at lower annealing temperature, which confirms the process of the combustion reaction. The electrical conductivity was greatly improved with $\mathrm{Zn}$ doping into the $\mathrm{NiO}_{x}$ crystal lattice. Better photoluminescence (PL) quenching, and low PL lifetime decay were responsible for better charge separation in $5 \% \mathrm{Zn}$ doped $\mathrm{NiO}_{x}$, which results in improved device performance of PSCs. The maximum power conversion efficiency of inverted PSCs made with pristine $\mathrm{NiO}_{x}$ and $5 \% \mathrm{Zn}-\mathrm{NiO}_{x}$ as the HTL was $13.62 \%$ and $14.87 \%$, respectively. Both the devices exhibited better stability than the PEDOT:PSS (control) device in an ambient condition.
\end{abstract}

Keywords: perovskite solar cells; hole transport layer; nickel oxide; combustion reaction; zinc doping; low temperature

\section{Introduction}

Researchers have promised that the perovskite solar cells (PSCs) could soon be released as a commercial product in the next few years [1,2]. PSCs have become a hot topic among researchers because of their superior optoelectronic properties [3-7]. The ease of device fabrication kept this device in the limelight among other next-generation solar cells [8]. In inverted PSCs, the most commonly used HTL is poly(3,4-ethylene dioxythiophene) polystyrene sulfonate (PEDOT:PSS); it can exhibit better device performance at lower processing temperature, but the stability of the device is worse because of its hygroscopic and acidic nature [9]. Replacing the organic PEDOT:PSS as hole transport layer (HTL) in perovskite solar cells with inorganic p-type metal oxide materials is an effective way to improve the device's performance and stability [10]. The basic requirement of the HTL is to be highly transparent throughout the solar spectra, good electrical conductivity, and a high work function for effective charge transport [11]. Among the various metal oxides, nickel oxide $\left(\mathrm{NiO}_{x}\right)$ is an ideal candidate for this special purpose [11-15]. In physical vapor deposition techniques, these metal oxides require special processing conditions, including a vacuum environment and heat treatment, etc. [16]. In contrast, solution-processed $\mathrm{NiO}_{x}$ has a variety of options that does not require any special processing conditions [17]. The preparation of the $\mathrm{NiO}_{x} \mathrm{HTL}$ by the sol-gel method requires it to be annealed at a high temperature above $300{ }^{\circ} \mathrm{C}$ to achieve high performance from the PSCs $[18,19]$. This hightemperature process increases the cost of device fabrication at an industrial scale and 
restricts the substrate options [20]. Low-temperature processing or crystallization of metal oxide thin films has become popular research in the last few years [21].

During the solution process, the temperature of $\mathrm{NiO}_{x}$ must be raised to a minimum of $275^{\circ} \mathrm{C}$ to commence converting the Ni precursor into $\mathrm{NiO}_{x}[22,23]$. Another means of implementing the sol-gel process is to employ combustion chemistry to create solutionprocessed transition metal oxide (TMO) films with high crystallinity without using high temperatures [24-27]. The unique properties of self-generated energy and exothermic reactions permit the use of lower processing temperatures, replacing sol-gel endothermic reactions that require high levels of thermal energy to enable the formation of TMO lattices and the removal of any organic impurity. Combustion chemistry has been employed for the successful preparation of a variety of TMO thin films and at lower temperatures than sol-gel technique. In PSCs, the combustion processed $\mathrm{NiO}_{x}$ was first reported by Bai et al. It was annealed at $175^{\circ} \mathrm{C}$, with glycine as a fuel [28]. Later, Jen et al. replaced glycine with acetylacetone and developed $\mathrm{NiO}_{x} \mathrm{HTL}$ at $150{ }^{\circ} \mathrm{C}$ [24]. Chang et al. used a similar method but annealed at $250^{\circ} \mathrm{C}$ and achieved a PCE of $20.2 \%$ for mixed cation PSCs [29]. Recently, Cai et al. studied the effect of various concentrations of fuel in the combustion processed $\mathrm{NiO}_{x}$ HTL for PSCs [30]. Zhang et al. improved the efficiency with a two-step coating of mixed perovskites [31]; however, the intrinsic electrical conductivity of $\mathrm{NiO}_{x}$ is very low, which restricts the device's performance. Metal ion doping into NiO can improve its electrical conductivity even at lower annealing temperatures. This has been successfully used in sol-gel processed $\mathrm{NiO}_{x}$ doped with various metal ions such as $\mathrm{Ag}$ [32], Cs [23], $\mathrm{Y}$ [33], K [34], Co [35], etc. Even in the combustion reaction, $\mathrm{Cu}$ doped $\mathrm{NiO}_{x}$ thin film was successfully developed as the HTL in inverted PSCs [24]. Influenced by this idea, we adopted this technique to prepare zinc doped $\mathrm{NiO}_{x}$ thin film as the HTL in PSCs.

Here, we report the successful development of $\mathrm{NiO}_{x}$ and $\mathrm{Zn}$ doped $\mathrm{NiO}_{x}$ at a relatively low annealing temperature as the HTL for inverted PSCs. It was achieved by utilizing combustion chemistry, which significantly reduces its actual reaction temperature compared with traditional sol-gel methods. The effect of $\mathrm{Zn}$ doping in $\mathrm{NiO}_{x}$ was studied by investigating the structural, morphological, and optoelectronic properties and the carrier dynamics of the films. The photovoltaic performance was analyzed and the average PCE of $\mathrm{NiO}_{x}$ and $5 \% \mathrm{Zn}$ doped $\mathrm{NiO}_{x}$ was $13.52 \%$ and $14.67 \%$, respectively. Overall, the device performance was significantly improved with $\mathrm{Zn}$ doping in the $\mathrm{NiO}_{x} \mathrm{HTL}$.

\section{Materials and Methods}

\subsection{Synthesis of $\mathrm{NiO}_{x}$ and $\mathrm{Zn}$ Doped $\mathrm{NiO}_{x}$ Thin Films}

Preparation of the $\mathrm{NiO}$ precursor solution took place as previously described [25] with certain adaptations. Briefly, $0.145 \mathrm{~g}$ of nickel nitrate hexahydrate underwent dissolution in $5 \mathrm{~mL}$ of 2-methoxyethanol; this solution underwent stirring for $30 \mathrm{~min}$ until complete dissolution of the precursor was achieved. This solution was then supplemented with $50 \mu \mathrm{L}$ of acetylacetonate and stirring was maintained overnight. Following this, a polytetrafluoroethylene (PTFE) syringe filter was used to filter the solution. To deposit the thin film, the precursor solution underwent spin coating onto a clean fluorine-doped tin oxide (FTO) substrate for $45 \mathrm{~s}$ at $2500 \mathrm{rpm}$. A hotplate was then used to anneal the spin-coated films in the air for one hour at $250{ }^{\circ} \mathrm{C}$. These prepared films were then given UV-ozone treatment for five minutes prior to being placed in the glovebox. To make the doping successful, zinc nitrate hexahydrate was used to replace the variety of mole percentages of nickel precursors.

\subsection{PSC Device Fabrication}

An ultrasonic bath was employed to clean the laser patterned FTO substrates in sequence with detergent, acetone, and IPA for $10 \mathrm{~min}$. Subsequently, drying of the substrate occurred employing a nitrogen gun and then exposed to ultraviolet (UV)-ozone treatment (15 min). A spin coater was used to deposit the $\mathrm{NiO}_{x}$ and $\mathrm{Zn}-\mathrm{NiO}_{x}$ thin films with annealing occurring at $250^{\circ} \mathrm{C}$ as previously described. Following cooling, these substrates were then 
placed in the glovebox. Following this, production of a perovskite active layer occurred by dissolving $1.4 \mathrm{M}$ methylammonium iodide (MAI) and $1.4 \mathrm{M}$ lead iodide $\left(\mathrm{PbI}_{2}\right)$ in $\gamma$ butyrolactone (GBL) and dimethyl sulfoxide (DMSO) (7:3). This solution was then subjected to overnight stirring inside the glove box at $60^{\circ} \mathrm{C}$. A $0.45-\mu \mathrm{m}$ PTFE syringe filter was used to filter the solution before deposition. The solution underwent spin coating onto FTO/NiO $x$ substrates (1000 rpm/15 s and $5000 \mathrm{rpm} / 25 \mathrm{~s}$ ). Toluene was employed as an anti-solvent and was added precisely five seconds prior to completing the second stage. Following this, the substrates were annealed for $10 \mathrm{~min}$ at $100{ }^{\circ} \mathrm{C}$. Preparation of the electron transport layer (ETL) was achieved in the following manner: $20 \mathrm{mg} / \mathrm{mL}$ of phenyl-C61-butyric acid methyl ester (PCBM) in 1,4-dichlorobenzene (DCB) underwent spin-coating onto the substrates at $2000 \mathrm{rpm}$ for $30 \mathrm{~s}$, and a saturated solution of bathocuproine (BCP) in methanol was dynamically spin-coated at $6000 \mathrm{rpm}$ for $30 \mathrm{~s}$. Lastly, thermal evaporation of an Ag electrode was achieved employing a metal mask.

\subsection{Characterization}

Characterization of the $\mathrm{NiO}_{x}$ and $\mathrm{Zn}-\mathrm{NiO}_{x}$ thin films was undertaken implying $\mathrm{X}$-ray diffraction (XRD) techniques using a Rigaku D/Max-2500V system (Rigaku Corp, Tokyo, Japan). The surface morphology and topography underwent inspection using a field emission scanning electron microscope (FESEM) (morphology) (JEOL JSM-7000F, JEOL Inc., Tokyo, Japan) and an atomic force microscope (AFM) (AutoProbe CP, Thermomicroscopes, Sunnyvale, CA, USA) (topography). Elemental composition analysis was undertaken using X-ray photoelectron spectroscopy (XPS) (Thermo K-Alpha, Thermo Fisher Scientific, Inc., Waltham, MA, USA). Measurement of UV-visible absorption and transmission spectra was undertaken employing a UV-Vis spectrophotometer (Hitachi U 3900, Tokyo, Japan). Measurements of steady-state photoluminescence (PL) and time-resolved photoluminescence (TRPL) were undertaken employing a solid-state laser $(\lambda=405 \mathrm{~nm}$, PDL 800-D, PICOQUANT, Berlin, Germany) equipped with a laser scanning confocal microscope and a spectrometer equipped with a thermoelectrically cooled charge-coupled detector (for PL) and a time-correlated single-photon counting detector (TCSPC) (for TRPL). Analysis of the PSC device performance was undertaken employing current density-voltage $(J-V)$ curves, external quantum efficiency (EQE), and electrochemical impedance spectroscopy (EIS). Measurement of PSC $J-V$ characteristics was undertaken using a 1 sun illumination (AM $1.5 \mathrm{G}$ spectrum) employing a $550 \mathrm{~W}$ Xenon lamp solar simulator (Sun 3000 Class AAA, Abet Technologies, Milford, MA, USA).

\section{Results and Discussion}

As mentioned, the $\mathrm{NiO}_{x}$ and $\mathrm{Zn}$ doped $\mathrm{NiO}_{x}$ thin films were prepared using the combustion spin-coating technique, and the films were annealed at a lower temperature $\left(250{ }^{\circ} \mathrm{C}\right)$ than the sol-gel technique. The inverted PSCs with an architecture of $\mathrm{FTO} / \mathrm{NiO}_{x} / \mathrm{MAPbI}_{3} / \mathrm{PCBM} / \mathrm{BCP} / \mathrm{Ag}$ were fabricated, as shown in Figure 1a. Figure 1b,c show the energy level diagram of inverted PSCs and the photograph of the fabricated device. The current density-voltage $(J-V)$ curves of the PSCs made with $\mathrm{NiO}_{x}$ and $\mathrm{Zn}$ doped $\mathrm{NiO}_{x}$ HTL are shown in Figure 2a. The device made with $5 \% \mathrm{Zn}-\mathrm{NiO}_{x}$ exhibited the best PCE of $14.87 \%$ versus pristine $\mathrm{NiO}_{x}(13.62 \%)$. The detailed device parameters of the PSCs made with both the $\mathrm{NiO}_{x}$ and $\mathrm{Zn}$ doped $\mathrm{NiO}_{x}$ thin films annealed at $250{ }^{\circ} \mathrm{C}$ are summarized in Table 1 . The results were reproducible and the average values were calculated from eight best devices from different batches. The devices performed well with $\mathrm{NiO}_{x} \mathrm{HTL}$ annealed at a relatively lower temperature. The current density (Jsc) of the pristine $\mathrm{NiO}_{x}$ device was improved with an increase in $\mathrm{Zn}$ doping and may be due to an improvement in the electrical conductivity of HTL. The lower doping concentration of $2 \% \mathrm{Zn}-\mathrm{NiO}_{x}$ exhibited relatively similar efficiency with a minimal increase in Jsc. The device made with $5 \% \mathrm{Zn}-\mathrm{NiO}_{x}$ showed improved Jsc and minimal reduction in $\mathrm{FF}$ and Voc. There was no significant change in Voc perhaps because there were no major changes in valence band edge position after $\mathrm{Zn}$ doping with lower concentration. The Voc and FF 
were decreased with further increasing of $\mathrm{Zn}$ concentration $(10 \%)$ into $\mathrm{NiO}_{x} \mathrm{HTL}$. It may be due to the higher $\mathrm{Zn}^{2+}$ dopant concentration induce the transformation of p-type to n-type $\mathrm{NiO}_{x}$, which results in poor device performance [36]. The $J-V$ characteristics revealed that the current flow across the device was increased due to the $\mathrm{Zn}$ doping into $\mathrm{NiO}_{x}$. The external quantum efficiency (EQE) spectra of the devices made using $\mathrm{NiO}_{x}$ and $\mathrm{Zn}$ doped $\mathrm{NiO}_{x}$ HTL are shown in Figure 2b. The devices made with $\mathrm{NiO}_{x}$ and $\mathrm{Zn}$ doped $\mathrm{NiO}_{x}$ films displayed satisfactory results throughout the entire visible region. In comparison, a similar kind of EQE curve was observed in all the devices. The increment in the EQE value for the $5 \% \mathrm{Zn}-\mathrm{NiO}_{x}$ device versus the pristine $\mathrm{NiO}_{x}$ device indicates the improvement in device performance. These results agreed with the $J-V$ characteristics results. Therefore, the pristine $\mathrm{NiO}_{x}$ and $5 \% \mathrm{Zn}-\mathrm{NiO}_{x}$ were chosen for further detailed studies.

(a)

(c)
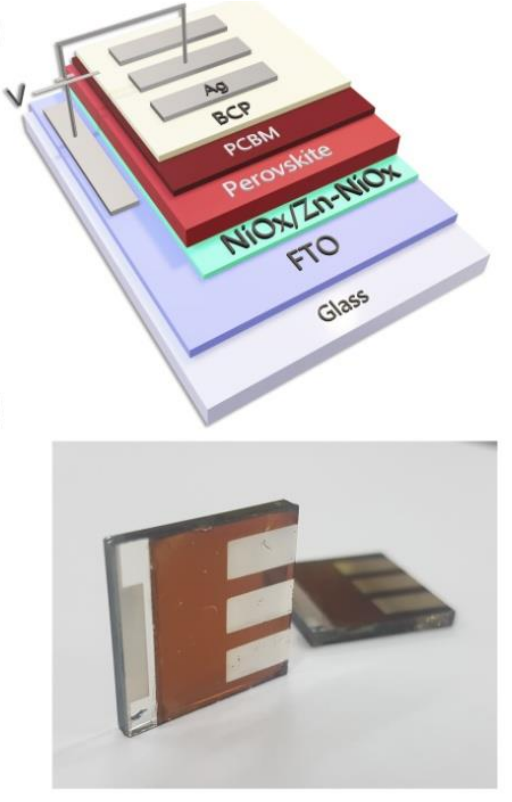

(b)

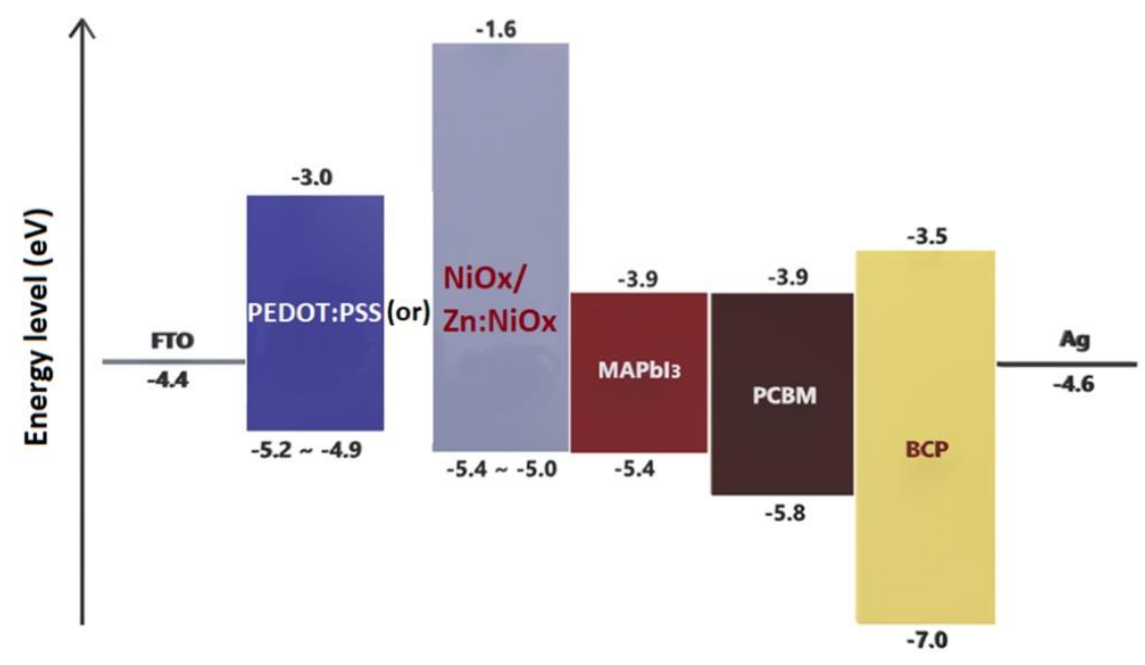

Figure 1. (a) Device architecture, (b) energy level diagram of inverted PSCs, and (c) photograph of the fabricated device.

(a)

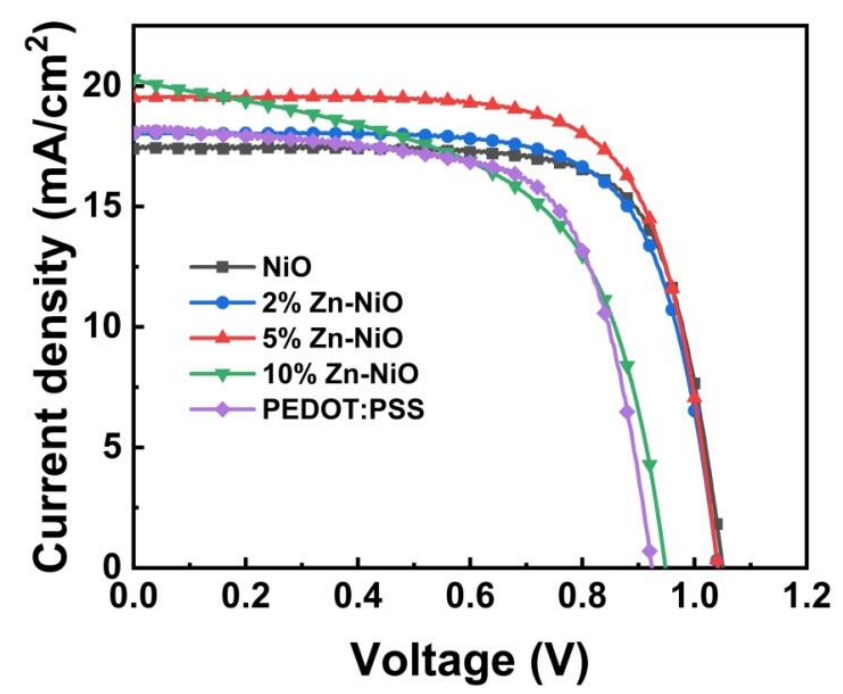

(b)

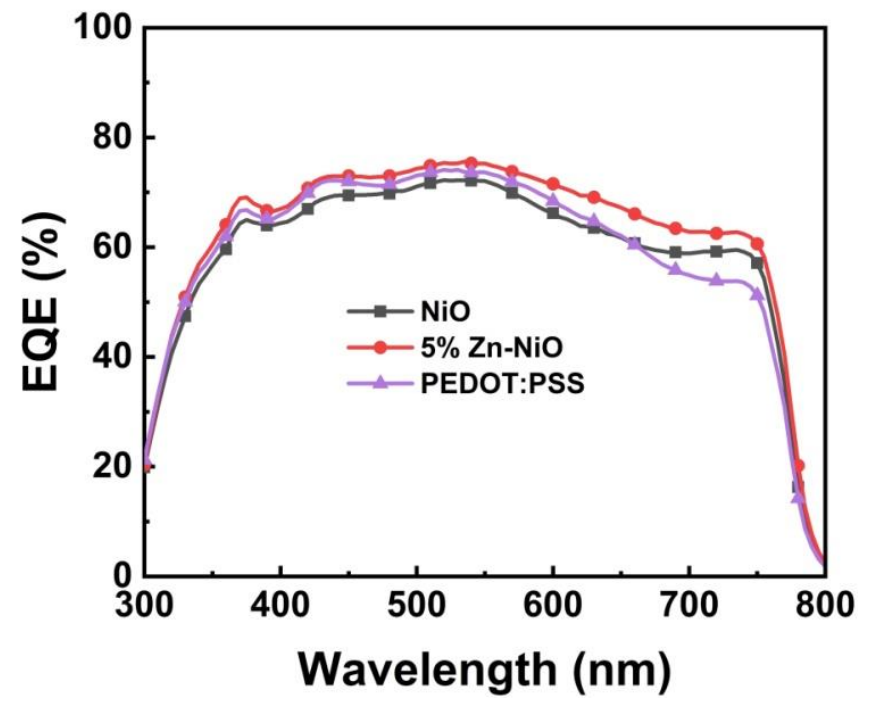

Figure 2. (a) $J-V$ characteristics and (b) EQE spectra of PSCs made with $\mathrm{NiO}_{x}, \mathrm{Zn}-\mathrm{NiO}_{x}$, and PEDOT: PSS (control) HTLs. 
Table 1. Summary of device performance of the PSCs made with $\mathrm{NiO}_{x}, \mathrm{Zn}-\mathrm{NiO}_{x}$, and PEDOT:PSS (control) HTLs.

\begin{tabular}{|c|c|c|c|c|c|c|c|}
\hline \multicolumn{2}{|c|}{ HTL } & \multirow{2}{*}{$\begin{array}{c}\operatorname{Voc}(\mathbf{V}) \\
1.047 \pm 0.01 \\
1.051 \\
\end{array}$} & \multirow{2}{*}{$\begin{array}{c}J s c\left(\mathbf{m A} / \mathbf{c m}^{2}\right) \\
17.47 \pm 0.16 \\
17.39\end{array}$} & \multirow{2}{*}{$\begin{array}{c}\text { FF } \\
0.74 \pm 0.01 \\
0.75\end{array}$} & \multirow{2}{*}{$\begin{array}{c}\text { PCE (\%) } \\
13.52 \pm 0.10 \\
13.62\end{array}$} & \multirow{2}{*}{$\begin{array}{c}\operatorname{Rs}\left(\Omega / \mathrm{cm}^{2}\right) \\
6.9\end{array}$} & \multirow{2}{*}{$\begin{array}{c}\begin{array}{c}R s h \\
\left(\mathbf{k} \Omega / \mathrm{cm}^{2}\right)\end{array} \\
2.59\end{array}$} \\
\hline $\mathrm{NiO}_{x}$ & $\begin{array}{l}\text { Average } \\
\text { best }\end{array}$ & & & & & & \\
\hline $2 \% \mathrm{Zn}-\mathrm{NiO}_{x}$ & $\begin{array}{c}\text { Average } \\
\text { best }\end{array}$ & $\begin{array}{c}1.045 \pm 0.02 \\
1.046\end{array}$ & $\begin{array}{c}17.87 \pm 0.42 \\
18.02\end{array}$ & $\begin{array}{c}0.73 \pm 0.01 \\
0.73\end{array}$ & $\begin{array}{c}13.61 \pm 0.15 \\
13.76\end{array}$ & 6.8 & 1.87 \\
\hline $5 \% \mathrm{Zn}-\mathrm{NiO}_{x}$ & $\begin{array}{c}\text { Average } \\
\text { best }\end{array}$ & $\begin{array}{c}1.046 \pm 0.01 \\
1.046\end{array}$ & $\begin{array}{c}19.26 \pm 0.62 \\
19.67\end{array}$ & $\begin{array}{c}0.73 \pm 0.02 \\
0.72\end{array}$ & $\begin{array}{c}14.67 \pm 0.20 \\
14.87\end{array}$ & 6.9 & 1.78 \\
\hline $10 \% \mathrm{Zn}-\mathrm{NiO}_{x}$ & $\begin{array}{c}\text { Average } \\
\text { best }\end{array}$ & $\begin{array}{c}0.942 \pm 0.01 \\
0.949\end{array}$ & $\begin{array}{c}20.17 \pm 0.19 \\
20.28\end{array}$ & $\begin{array}{c}0.57 \pm 0.01 \\
0.57\end{array}$ & $\begin{array}{c}10.77 \pm 0.13 \\
10.90\end{array}$ & 9.2 & 0.19 \\
\hline $\begin{array}{c}\text { Control } \\
\text { PEDOT:PSS }\end{array}$ & $\begin{array}{c}\text { Average } \\
\text { best }\end{array}$ & $\begin{array}{c}0.905 \pm 0.02 \\
0.925\end{array}$ & $\begin{array}{c}17.91 \pm 0.46 \\
18.03\end{array}$ & $\begin{array}{c}0.68 \pm 0.01 \\
0.69\end{array}$ & $\begin{array}{c}11.21 \pm 0.22 \\
11.43\end{array}$ & 7.5 & 0.45 \\
\hline
\end{tabular}

Apart from the performance provided by the HTL, it has a strong impact on the stability of PSCs. This study performed an investigation on the stability of unencapsulated devices stored in dark conditions at room temperature with about $40 \%$ of relative humidity. Figure $3 \mathrm{a}, \mathrm{b}$ show the stability graph and the photograph of PSCs based on PEDOT:PSS, $\mathrm{NiO}_{x}$, and $5 \% \mathrm{Zn}-\mathrm{NiO}_{x} \mathrm{HTLs}$, respectively. It can be seen that the device made with PEDOT:PSS degrades fast and lost its total efficiency in 4 days. The fast degradation of perovskite happened at the active area of PEDOT:PSS device was due to the reaction of Ag electrodes with volatile degradation products from the perovskite and ion migration. The acidic and hygroscopic nature of PEDOT:PSS degrades the $\mathrm{MAPbI}_{3}$ into $\mathrm{PbI}_{2}$ and releases its by-products in the form of $\mathrm{I}_{2}, \mathrm{CH}_{3} \mathrm{I}$, and $\mathrm{HI}$, which can readily react with $\mathrm{Ag}$ to form $\mathrm{AgI}$ [37]. By contrast, the rate of degradation is usually very slow in $\mathrm{NiO}_{x}$ based PSCs. Both $\mathrm{NiO}_{x}$ and $5 \% \mathrm{Zn}-\mathrm{NiO}_{x}$ based PSCs have retained $80 \%$ of their initial efficiency after $108 \mathrm{~h}$.

(a)

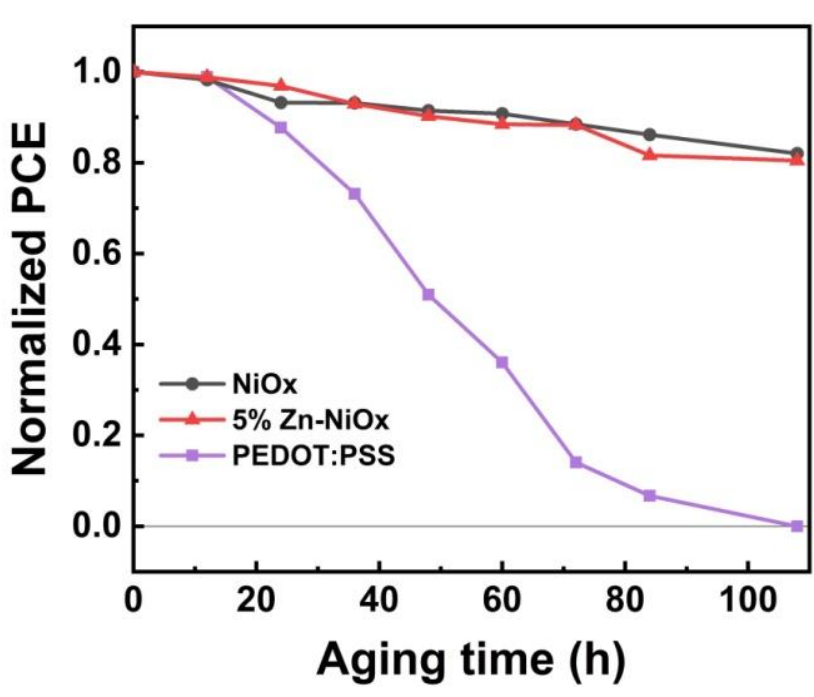

(b)

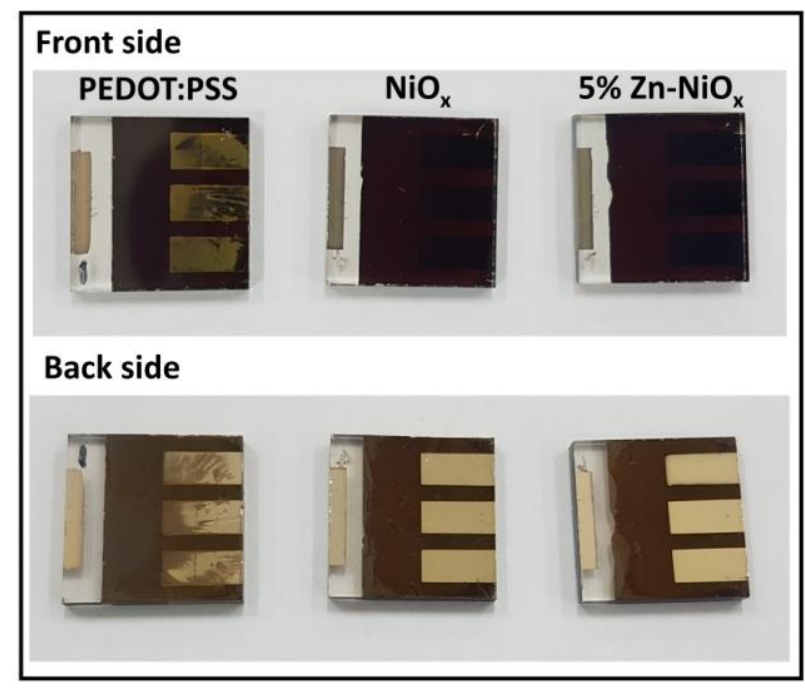

Figure 3. (a) Stability graph and (b) photograph of the PSCs made with $\mathrm{NiO}_{x}, 5 \% \mathrm{Zn}-\mathrm{NiO}_{x}$, and PEDOT: PSS (control) HTLs without encapsulation (under ambient air at room temperature for 4 days).

The XRD pattern of $\mathrm{NiO}_{x}$ and $5 \% \mathrm{Zn}-\mathrm{NiO}_{x}$ thin films on glass substrate and annealed at $250{ }^{\circ} \mathrm{C}$ is shown in Figure 4 . The cubic structure of $\mathrm{NiO}$ has peaked at $37.3^{\circ}, 43.3^{\circ}$, and $62.9^{\circ}$, corresponding to the hkl value of (111), (002), and (022), respectively. This can be observed in both $\mathrm{NiO}_{x}$ and $5 \% \mathrm{Zn}-\mathrm{NiO}_{x}$ thin films. It clearly shows that thin films had 
poor polycrystalline nature but significantly higher crystallinity than the film annealed at $250^{\circ} \mathrm{C}$ in the sol-gel process in previous work [38], and similar kinds of results were reported $[29,33]$. This result shows that the formation of $\mathrm{NiO}_{x}$ occurred below the actual reaction temperatures. It confirms the process of the combustion reaction.

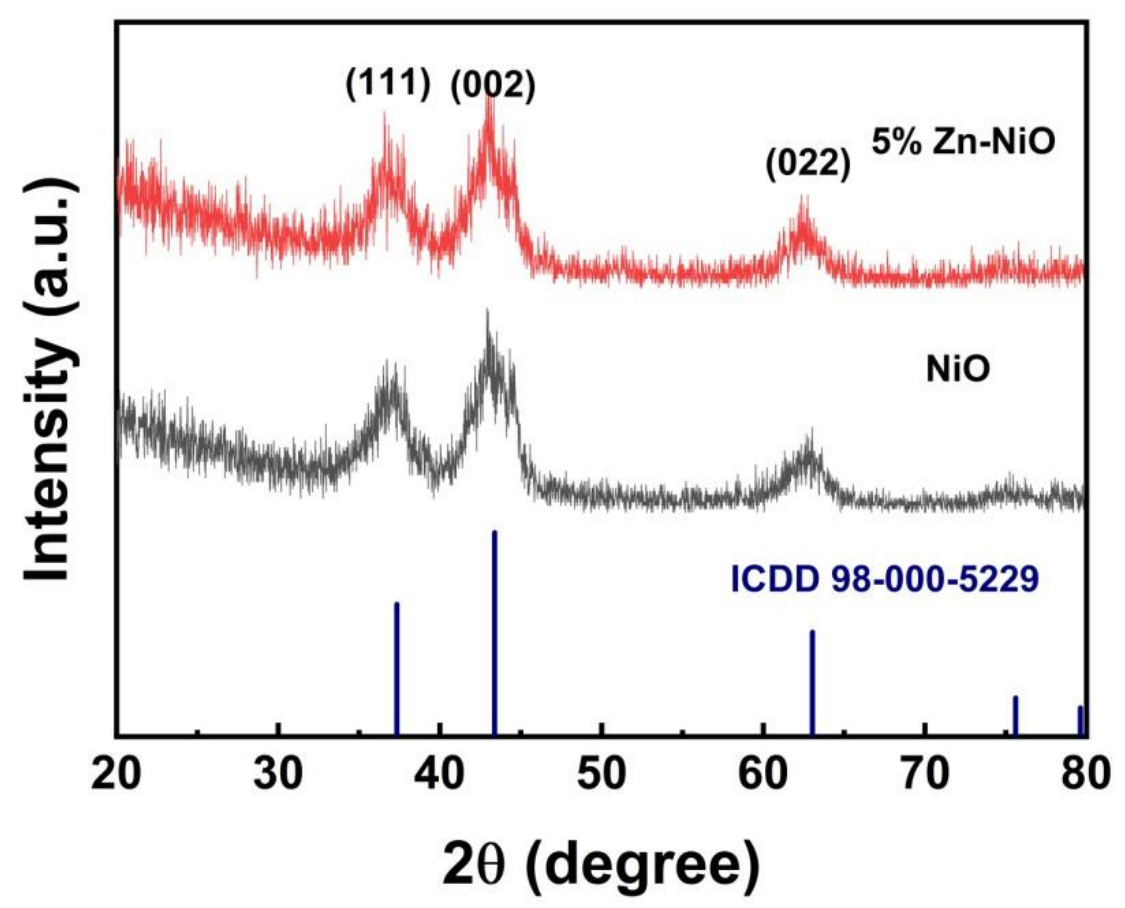

Figure 4. XRD patterns of $\mathrm{NiO}_{x}$ and $5 \% \mathrm{Zn}-\mathrm{NiO}_{x}$ thin films.

X-ray photoelectron spectroscopy (XPS) was used to analyze the elemental composition of the $\mathrm{NiO}_{x}$ and $5 \% \mathrm{Zn}-\mathrm{NiO}_{x}$ thin films annealed at $250{ }^{\circ} \mathrm{C}$. Figure $5 \mathrm{a}$,b illustrate the XPS spectra for the Ni $2 \mathrm{p}$ and $\mathrm{O} 1 \mathrm{~s}$ core levels of $\mathrm{NiO}_{x}$ and $5 \% \mathrm{Zn}-\mathrm{NiO}_{x}$ thin films. The $\mathrm{NiO}_{x}$ peaks primarily comprise $\mathrm{Ni}^{2+}$ and $\mathrm{Ni}^{3+}$ states. At $861 \mathrm{eV}$, there is a satellite peak attributable to the $\mathrm{NiO}_{x}$ shake-up process. The deconvoluted peak at $854 \mathrm{eV}$ corresponds with $\mathrm{NiO}\left(\mathrm{Ni}^{2+}\right), 856 \mathrm{eV}$ with $\mathrm{Ni}_{2} \mathrm{O}_{3}\left(\mathrm{Ni}^{3+}\right)$, and $857 \mathrm{eV}$ with $\mathrm{NiOOH}$ [39]. Similarly, the $\mathrm{O} 1 \mathrm{~s}$ spectra has three peaks, the deconvoluted peak at $529 \mathrm{eV}$ corresponding with $\mathrm{NiO}$ $\left(\mathrm{Ni}^{2+}\right), 531 \mathrm{eV}$ with $\mathrm{Ni}_{2} \mathrm{O}_{3}\left(\mathrm{Ni}^{3+}\right)$, and $533 \mathrm{eV}$ with $\mathrm{NiOOH}$. Generally, $\mathrm{Ni}^{3+}$ states cause p-type conductivity, indicating that quasi-localized holes have been formed around the lattice position's $\mathrm{Ni}^{2+}$ vacancies [40]. There is a higher $\mathrm{Ni}^{3+}$ state with $5 \% \mathrm{Zn}-\mathrm{NiO}_{x}$ versus pristine $\mathrm{NiO}_{x}$ as seen in the spectra of $\mathrm{Ni} 2 p$ and $\mathrm{O} 1 \mathrm{~s}$. This was due to the replacement of the $\mathrm{Ni}$ atom with $\mathrm{Zn}$ in the crystal lattice. $\mathrm{Zn}$ incorporation could alter the electronic structure of $\mathrm{NiO}_{x}$. The increase in the $\mathrm{Ni}^{3+}$ state denotes the presence of more $\mathrm{Ni}$ vacancies. The higher $\mathrm{Ni}^{3+} / \mathrm{Ni}^{2+}$ ratio in $5 \% \mathrm{Zn}-\mathrm{NiO}_{x}$ indicates the reduction in ionization energy of the $\mathrm{Ni}$ vacancies and increased hole density [41]. The successful incorporation of $\mathrm{Zn}$ in $\mathrm{NiO}_{x}$ can be seen in Figure $5 c$,d. The divalent state of $\mathrm{Zn}$ peaks of $2 p_{3 / 2}$ and $2 p_{1 / 2}$ were observed at $1021 \mathrm{eV}$ and $1045 \mathrm{eV}$, respectively. 
(a)

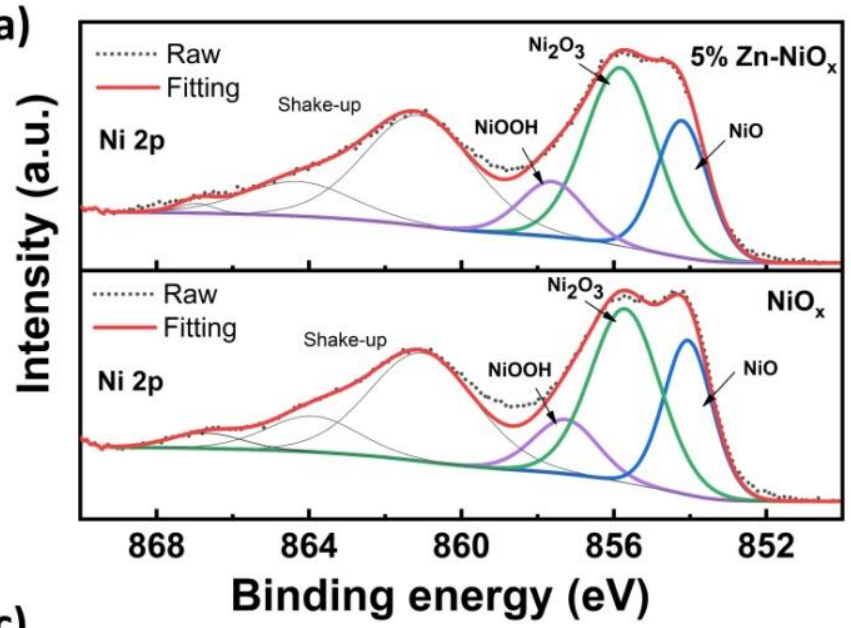

(c)

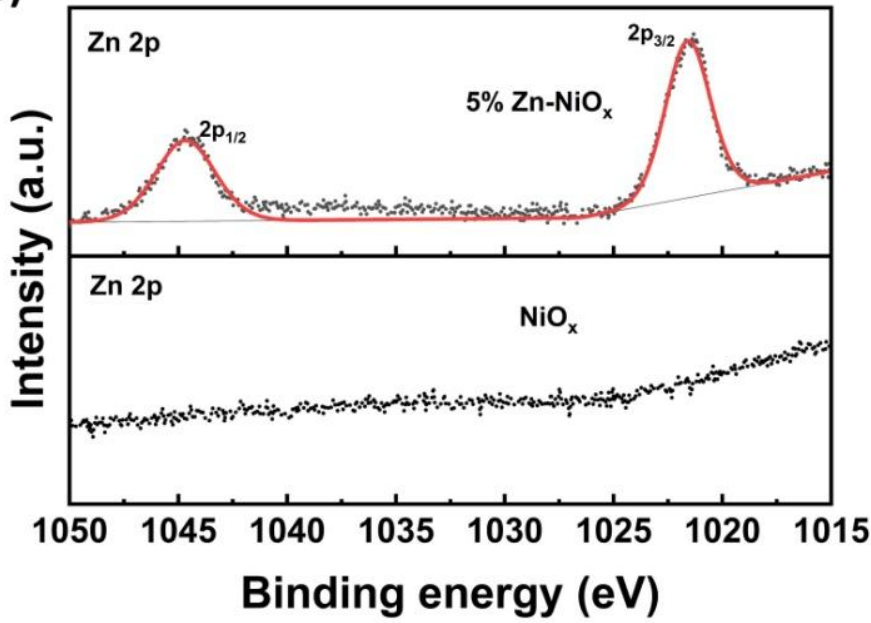

(b)
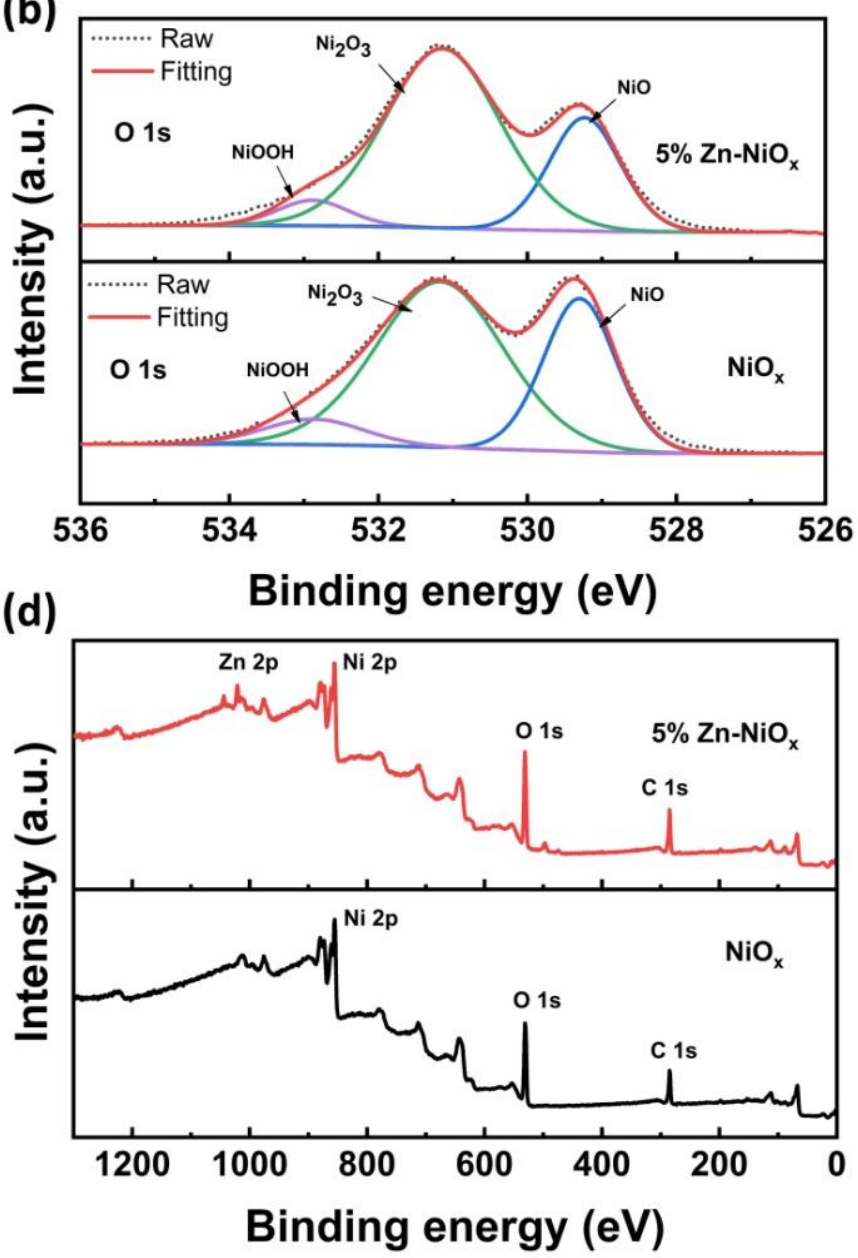

Figure 5. XPS spectra of (a) Ni $2 p$, (b) O 1s, (c) $\mathrm{Zn} 2 p$, and (d) survey scan for $\mathrm{NiO}_{x}$ and $5 \% \mathrm{Zn}-\mathrm{NiO}_{x}$ thin films.

The surface morphology of $\mathrm{NiO}_{x}$ and $5 \% \mathrm{Zn}-\mathrm{NiO}_{x}$ thin films annealed at $250{ }^{\circ} \mathrm{C}$ was analyzed by field emission scanning electron microscopy (FESEM). The top view of the FESEM image and energy-dispersive $\mathrm{X}$-ray spectroscopy (EDS) results for $\mathrm{NiO}_{x}$ and $5 \%$ $\mathrm{Zn}-\mathrm{NiO}_{x}$ thin films are shown in Figure $6 \mathrm{a}, \mathrm{b}$, respectively. Both films exhibit similar morphology and better coverage without any voids on FTO substrate. A fine layer of these thin films is clearly seen on the FTO, and the $5 \% \mathrm{Zn}$ doped $\mathrm{NiO}_{x}$ film looks somewhat smoother than the pristine film. This observation was confirmed by AFM results. EDS results confirmed the presence of $\mathrm{Zn}$ in $\mathrm{NiO}_{x}$ thin films. The atomic composition ratio was closely related to stoichiometry. Figure $6 \mathrm{c}$ shows the cross-sectional FESEM image of the device. The device was fabricated with an architecture of $\mathrm{FTO} / \mathrm{NiO}_{x} / \mathrm{MAPbI}_{3} / \mathrm{PCBM} / \mathrm{BCP} / \mathrm{Ag}$. All layers can be well distinguished from the cross-sectional FESEM image. 

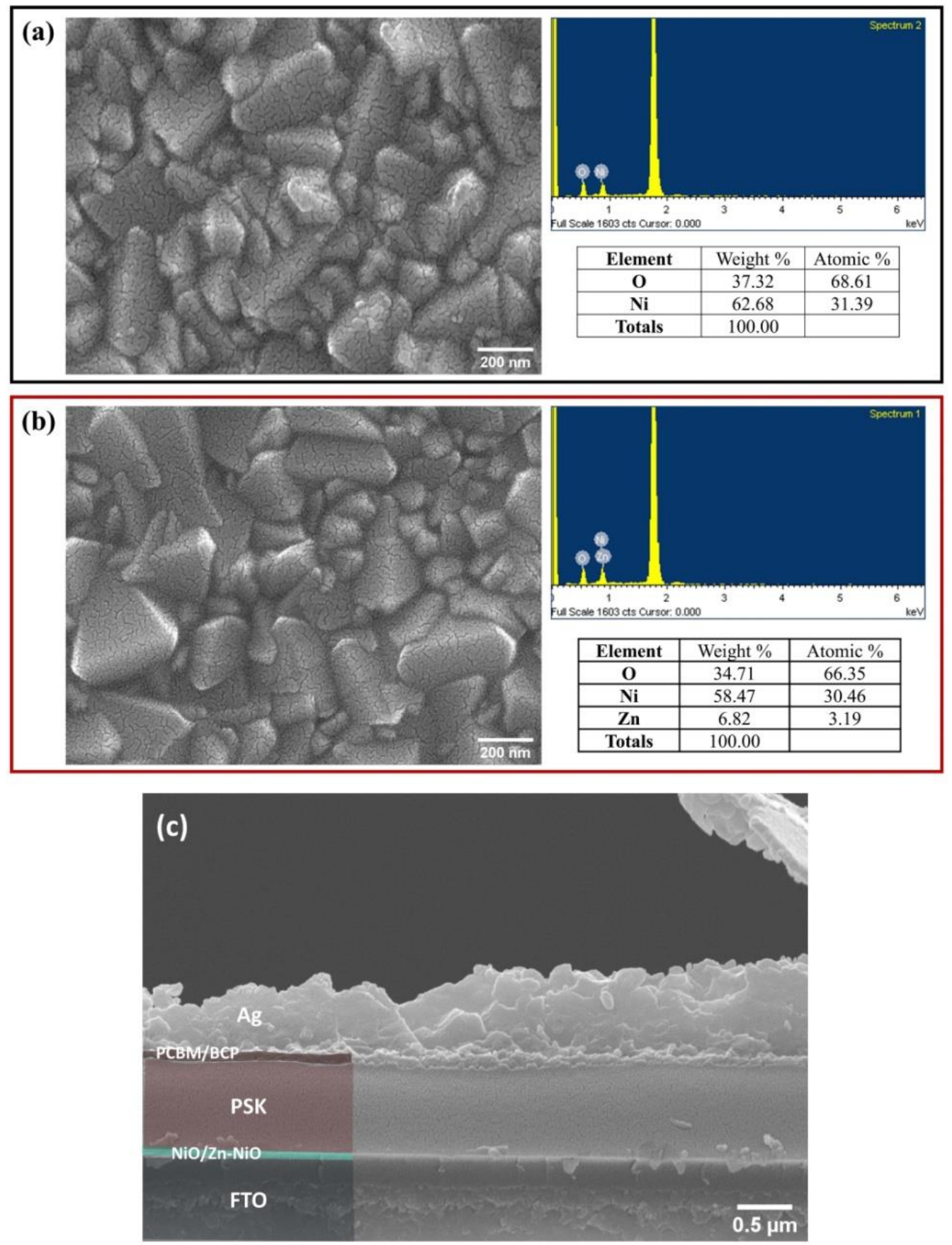

Figure 6. FESEM image and EDS result of (a) $\mathrm{NiO}_{x}$ and (b) $5 \% \mathrm{Zn}-\mathrm{NiO}_{x}$ thin films, (c) cross-sectional FESEM image of the device.

Figure $7 \mathrm{a}, \mathrm{b}$ show the AFM images of $\mathrm{NiO}_{x}$ and $5 \% \mathrm{Zn}-\mathrm{NiO}_{x}$ thin films annealed at $250{ }^{\circ} \mathrm{C}$. The films exhibited similar smooth and compact surface topography on FTO substrates for both $\mathrm{NiO}_{x}$ and $5 \% \mathrm{Zn}-\mathrm{NiO}_{x}$. The root-mean-squared (RMS) roughness values of $\mathrm{NiO}_{x}$ and $5 \% \mathrm{Zn}-\mathrm{NiO}_{x}$ are $37.1 \mathrm{~nm}$ and $33.9 \mathrm{~nm}$, respectively. The roughness of the film decreased with $\mathrm{Zn}$ doping because of the tendency of $\mathrm{ZnO}$ to form a crystalline nature at the lower annealing temperature [42]. This result is well-matched with other literature reports $[41,43]$. 

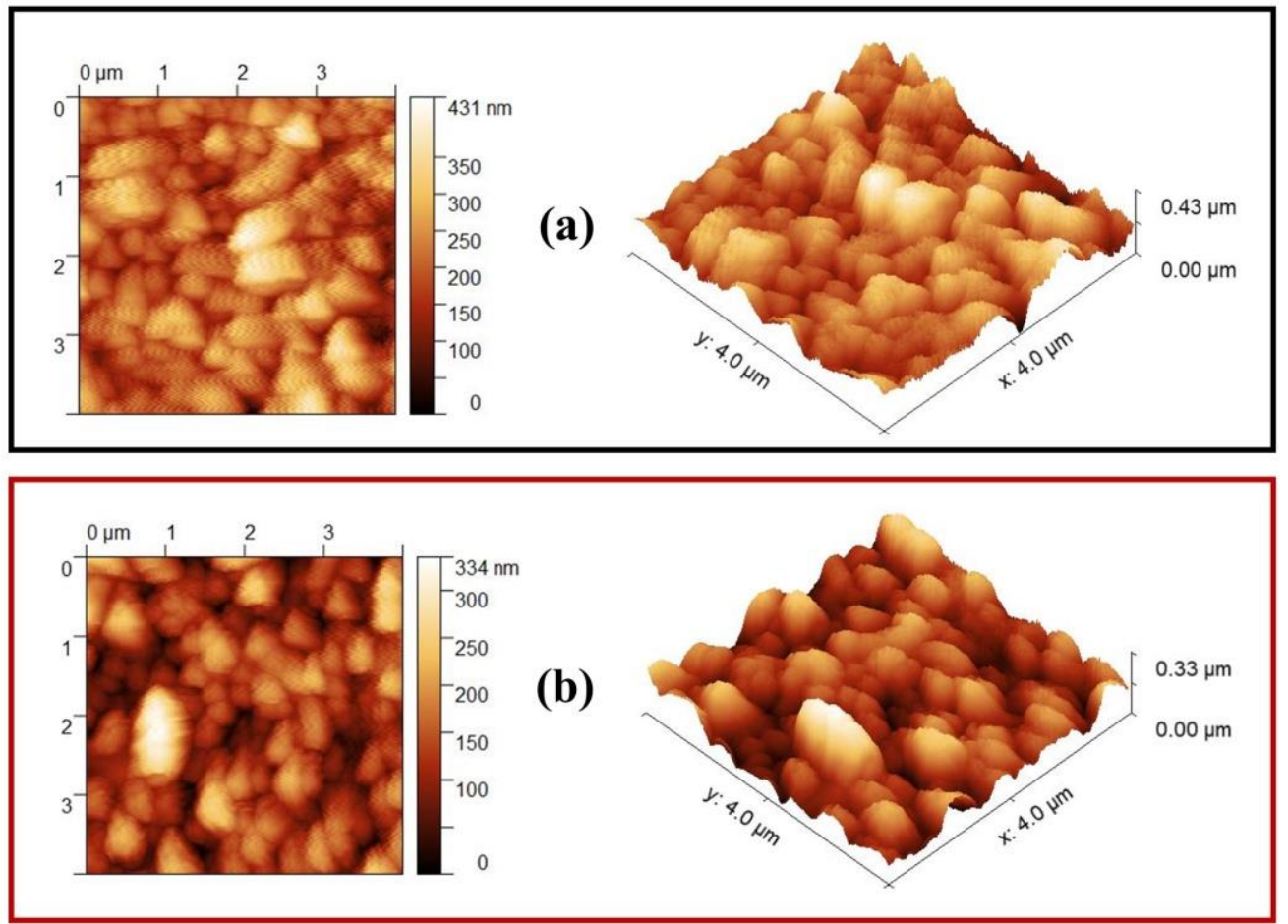

Figure 7. AFM images of (a) $\mathrm{NiO}_{x}$ and (b) $5 \% \mathrm{Zn}-\mathrm{NiO}_{x}$ thin films.

Figure 8a illustrates the transmittance spectra for $\mathrm{NiO}_{x}$ and $5 \% \mathrm{Zn}-\mathrm{NiO}_{x}$ thin films that underwent annealing at $250^{\circ} \mathrm{C}$. Each film showed a high transmittance level within the visible spectrum range, with average values being above $80 \%$. Figure $8 \mathrm{~b}$ illustrates the graph of absorption coefficient as a function of excitation energy; calculation of the optical bandgap value was undertaken through an additional plot of the linear portion of $(\alpha \mathrm{h} v)^{2}$ to the $x$-axis employing a Tauc plot [44]. This bandgap value $\left(\mathrm{E}_{\mathrm{g}}\right)$ was around $3.95 \mathrm{eV}$ both for $\mathrm{NiO}_{x}$ and $5 \% \mathrm{Zn}-\mathrm{NiO}_{x}$ thin films. Very high HTL transmittance is required for minimization of incident light loss for enhancement of the light that reaches the perovskite layer. Any variations in optical properties when $\mathrm{Zn}$ is incorporated into $\mathrm{NiO}_{x}$ are minimal due to lower film thicknesses ( $20 \mathrm{~nm})$.

(a)

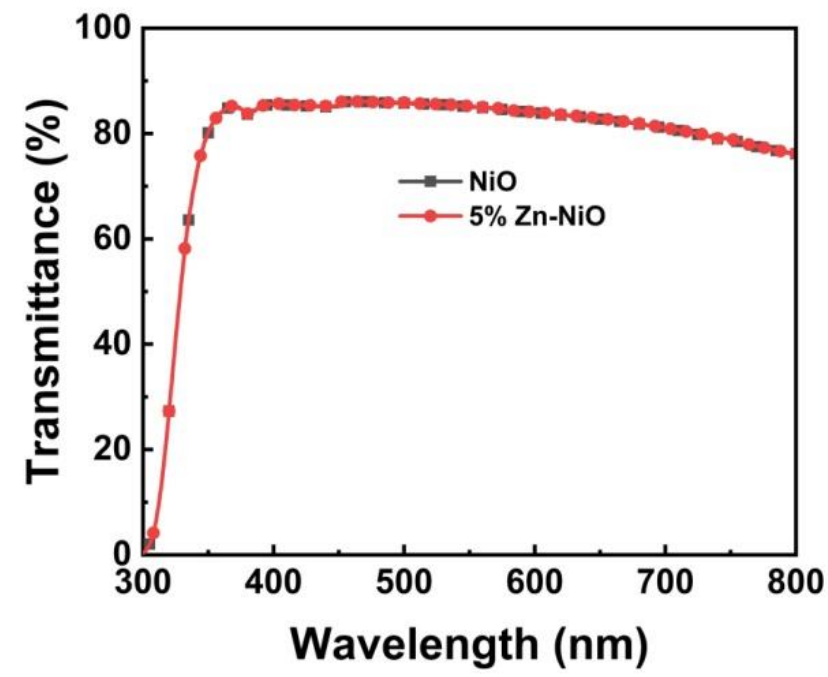

(b)

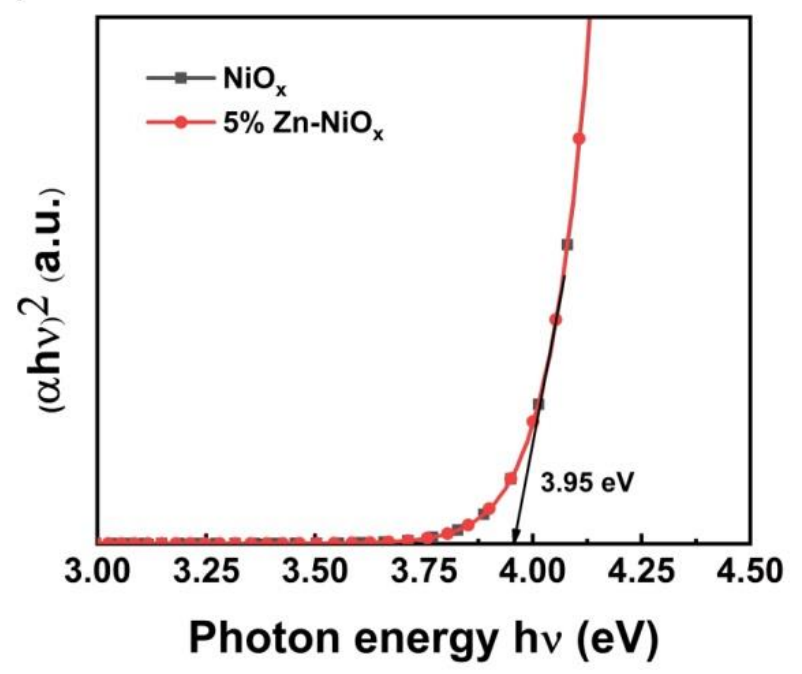

Figure 8. (a) Transmittance spectra and (b) Tauc plots of $\mathrm{NiO}_{x}$ and $5 \% \mathrm{Zn}-\mathrm{NiO}_{x}$ thin films. 
The impact of $\mathrm{Zn}$ doping on $\mathrm{NiO}_{x}$ thin-film electrical conductivity was examined by measuring the current-voltage $(I-V)$ characteristics of the hole-only device (FTO/ $\left.\mathrm{NiO}_{x} / \mathrm{Ag}\right)$. Figure 9 shows the $I-V$ curves for the hole-only devices based on $\mathrm{NiO}_{x}$ and $5 \% \mathrm{Zn}-\mathrm{NiO}_{x}$ thin films that underwent annealing at $250{ }^{\circ} \mathrm{C}$. This demonstrates that there are improvements in electrical conductivity when $\mathrm{Zn}$ doping is applied as the dopants have a high level of affinity with electrons.

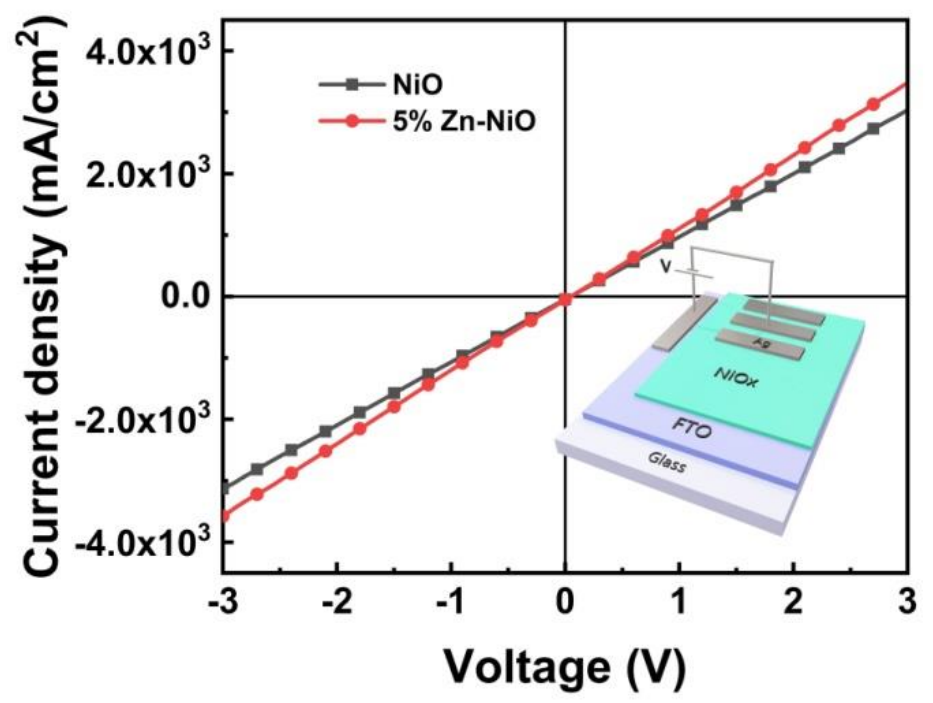

Figure 9. $I-V$ characteristics of hole-only devices made with $\mathrm{NiO}_{x}$ and $5 \% \mathrm{Zn}-\mathrm{NiO}_{x}$ thin films.

Charge extraction and non-radiative recombination at the perovskite and HTL interface was evaluated using steady-state photoluminescence (PL) and time-resolved photoluminescence (TRPL). Figure 10a,b show the PL spectrum and TRPL profile for perovskite films over $\mathrm{NiO}_{x}$ and $5 \% \mathrm{Zn}-\mathrm{NiO}_{x}$ thin films. The offset in the valence band edge plays a major role in charge recombination. Mismatches in the valence band edge between HTL and perovskite layer leads to more recombination at the interface and results in lowering of the Voc [45]. PL exhibited by the perovskite layer was significantly reduced by the HTLs. Noteworthy levels of PL quenching were shown with both types of film, demonstrating high levels of efficiency of charge extraction for $\mathrm{Zn}$ doped $\mathrm{NiO}_{x}$ thin films. These findings accord with previous research [43]. The TRPL profile was measured employing timecorrelated single-photon counting. Calculation of the PL lifetime decay was undertaken using tail fit with a biexponential decay function, as shown in Equation (1),

$$
y=y_{0}+A_{1} e^{-\left(x-x_{0}\right) / \tau_{1}}+A_{2} e^{-\left(x-x_{0}\right) / \tau_{2}}
$$

where $\tau_{1}$ represents the photogenerated excitons diffusing into defects, and $\tau_{2}$ representing intrinsic electron-hole recombination. The formula illustrated in Equation (2) was employed for the calculation of average PL lifetime values [46]; a detailed summary of these values can be found in Table 2 .

$$
\tau_{\text {avg }}=\left(\Sigma_{i} A_{i} \tau_{i}^{2}\right) /\left(\Sigma_{i} A_{i} \tau_{i}\right)
$$

Table 2. PL lifetime parameters from the fitting curves of $\mathrm{NiO}_{x}$ and $5 \% \mathrm{Zn}-\mathrm{NiO}_{x}$ thin films.

\begin{tabular}{cccccc}
\hline Sample & $\boldsymbol{A}_{\mathbf{1}}(\mathbf{\%})$ & $\boldsymbol{\tau}_{\mathbf{1}}(\mathbf{n s})$ & $\boldsymbol{A}_{\mathbf{2}}(\mathbf{\%})$ & $\boldsymbol{\tau}_{\mathbf{2}}(\mathbf{n s})$ & $\boldsymbol{\tau}_{\text {avg }}(\mathbf{n s})$ \\
\hline FTO/PSK & 69.4 & 20.4 & 30.6 & 46.0 & 33.2 \\
$\mathrm{FTO} / \mathrm{NiO}_{\mathrm{x}} / \mathrm{PSK}$ & 84.9 & 4.3 & 15.1 & 17.9 & 10.1 \\
$\mathrm{FTO} / 5 \% \mathrm{Zn}-\mathrm{NiO}_{\mathrm{x}} / \mathrm{PSK}$ & 82.0 & 4.4 & 18.0 & 15.6 & 9.3 \\
\hline
\end{tabular}


(a)

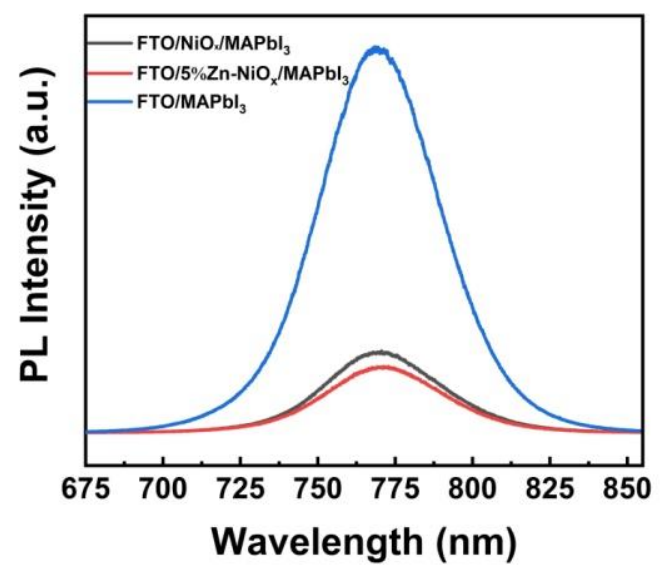

(b)

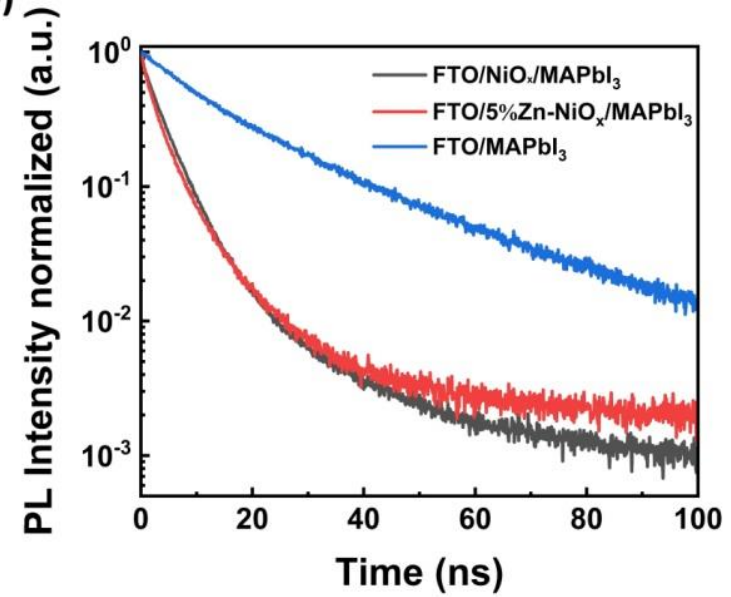

Figure 10. (a) PL spectra and (b) PL lifetime decay of $\mathrm{NiO}_{x}$ and $5 \% \mathrm{Zn}-\mathrm{NiO}$ thin films.

This research employed EIS measurements to undertake further verification of $\mathrm{NiO}_{x}$ and $5 \% \mathrm{Zn}-\mathrm{NiO}_{x}$ thin film-based devices' charge transport properties. Figure 11 illustrates the Nyquist plots for devices fabricated using $\mathrm{NiO}_{x}$ and $5 \% \mathrm{Zn}-\mathrm{NiO}_{x}$ thin films annealed at $250{ }^{\circ} \mathrm{C}$. EIS measurement was taken at one solar illumination using a frequency range from $10 \mathrm{~Hz}$ to $1 \mathrm{MHz}$ with an AC amplitude of $0.01 \mathrm{~V}$, and providing a bias voltage that matched the open-circuit voltage. The impedance curve was observed at three frequency regions where the high-frequency $(\mathrm{HF})$ regime correlates with charge transport resistance (Rct) at the HTL/perovskite interface, mid-frequency (MF) region is related to charge recombination, and low-frequency (LF) has been associated to iodide ion modulated recombination/injection process [47]. The curves were fitted with the equivalent circuit and the calculated Rct values are $\sim 60.38 \Omega$ and $45.62 \Omega$ for $\mathrm{NiO}_{x}$ and $5 \% \mathrm{Zn}-\mathrm{NiO}_{x}$ devices, respectively. Typically, low impedance values are expected for better carrier transport functions $[48,49]$. The device fabricated using $\mathrm{Zn}$ doped $\mathrm{NiO}_{x}$ had lower impedance values than those fabricated using pristine $\mathrm{NiO}_{x}$. It is clear that interface charge accumulation is suppressed, thus, improving exciton charge separation. Improved charge separation leads to increase in EQE and JSC values. These findings clearly indicate that charge transport at the HTL-perovskite interfaces can be improved by doping $\mathrm{NiO}_{x}$ with $\mathrm{Zn}$, leading to a general improvement in the performance of $\mathrm{NiO}_{x} \mathrm{HTL}$.

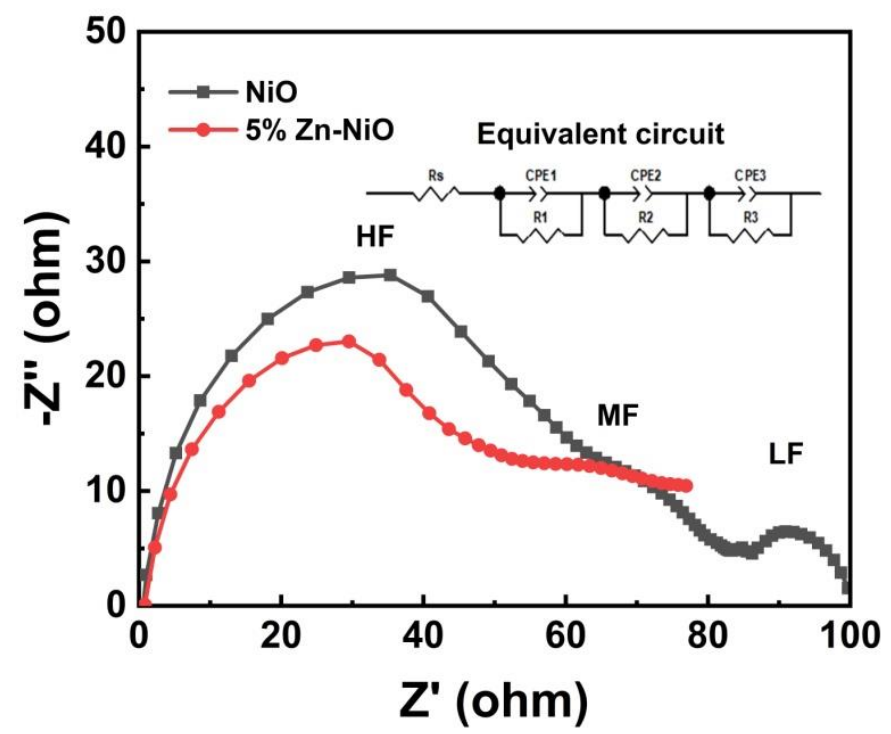

Figure 11. EIS spectra of PSCs with $\mathrm{NiO}_{x}$ and $5 \% \mathrm{Zn}-\mathrm{NiO}_{x} \mathrm{HTL}$. 


\section{Conclusions}

In this work, we investigated the effect of extrinsic Zn doping in $\mathrm{NiO}_{x} \mathrm{HTL}$ in inverted PSCs by the combustion technique. Comparatively, the devices made with both pristine and $\mathrm{Zn}$ doped $\mathrm{NiO}_{x}$ films performed well with the annealing temperature of $250{ }^{\circ} \mathrm{C}$, showing average PCE values of $13.62 \%$ and $14.87 \%$, respectively. Both the devices have exhibited better stability than the PEDOT:PSS (control) device in an ambient condition. The crystallinity of both pristine and $\mathrm{Zn}$ doped $\mathrm{NiO}_{x}$ films is better than the sol-gel derived thin film annealed at $250^{\circ} \mathrm{C}$. The XPS results revealed that the presence of compound formation below its reaction temperature and intensity of the $\mathrm{Ni}^{3+}$ peak (Ni vacancy) was higher in $\mathrm{Zn}$ doped $\mathrm{NiO}_{x}$ than the $\mathrm{NiO}_{x}$ film. The presence of $\mathrm{Zn}$ in $\mathrm{NiO}_{x}$ was confirmed in XPS but not observed in XRD. Both films exhibited similar optical transparency, and the effect of $\mathrm{Zn}$ incorporation on optical properties is negligible. The electrical conductivity was greatly improved with $\mathrm{Zn}$ doping into the $\mathrm{NiO}_{x}$ crystal lattice. The better PL quenching and low PL lifetime decay responsible for better charge separation were observed in $\mathrm{Zn}$ doped $\mathrm{NiO}_{x}$. A small impedance value from the $\mathrm{Zn}$ doped device showed less transport charge resistance than the pristine one. Overall, the $\mathrm{NiO}_{x}$ thin films made by the combustion technique were the films annealed at $250^{\circ} \mathrm{C}$, which can work as HTL in inverted PSCs. The performance of combustion processed $\mathrm{NiO}_{x}$ HTL was improved by Zn doping, showing better efficiency and overall superior performance than pristine $\mathrm{NiO}_{x}$ films.

Author Contributions: Conceptualization, C.-H.T. and P.S.T.; methodology, C.-H.T., P.S.T. and C.C.L.; validation, C.-H.T.; formal analysis, C.-H.T., P.S.T. and C.-C.L.; investigation, C.-H.T., P.S.T. and C.-C.L.; resources, C.-H.T.; data curation, C.-H.T., P.S.T. and C.-C.L.; writing-original draft preparation, C.-H.T. and P.S.T.; writing—review and editing, C.-H.T. and P.S.T.; supervision, C.-H.T.; project administration, C.-H.T.; funding acquisition, C.-H.T. All authors have read and agreed to the published version of the manuscript.

Funding: This research was funded by Ministry of Science and Technology (MOST) of Taiwan (Grant No. MOST 108-2221-E-259-011).

Institutional Review Board Statement: Not applicable.

Informed Consent Statement: Not applicable.

Data Availability Statement: The data in this work are available on request from the corresponding author.

Conflicts of Interest: The authors declare no conflict of interest.

\section{References}

1. Perovskite Solar Out-Benches Rivals in 2021-IEEE Spectrum. Available online: https:/ /spectrum.ieee.org/tech-talk/energy / renewables/oxford-pv-sets-new-record-for-perovskite-solar-cells (accessed on 18 March 2021).

2. Perovskite Solar I Perovskite-Info. Available online: https://www.perovskite-info.com/perovskite-solar (accessed on 18 March 2021).

3. Kojima, A.; Teshima, K.; Shirai, Y.; Miyasaka, T. Organometal halide perovskites as visible-light sensitizers for photovoltaic cells. J. Am. Chem. Soc. 2009, 131, 6050-6051. [CrossRef] [PubMed]

4. Kulkarni, S.A.; Baikie, T.; Boix, P.P.; Yantara, N.; Mathews, N.; Mhaisalkar, S. Band-gap tuning of lead halide perovskites using a sequential deposition process. J. Mater. Chem. A 2014, 2, 9221-9225. [CrossRef]

5. Noh, J.H.; Im, S.H.; Heo, J.H.; Mandal, T.N.; Seok, S. Il Chemical management for colorful, efficient, and stable inorganic-organic hybrid nanostructured solar cells. Nano Lett. 2013, 13, 1764-1769. [CrossRef] [PubMed]

6. Stranks, S.D.; Eperon, G.E.; Grancini, G.; Menelaou, C.; Alcocer, M.J.P.; Leijtens, T.; Herz, L.M.; Petrozza, A.; Snaith, H.J. Electronhole diffusion lengths exceeding 1 micrometer in an organometal trihalide perovskite absorber. Science 2013, 342, 341-344. [CrossRef] [PubMed]

7. Dong, Q.; Fang, Y.; Shao, Y.; Mulligan, P.; Qiu, J.; Cao, L.; Huang, J. Electron-hole diffusion lengths > $175 \mu \mathrm{m}$ in solution-grown $\mathrm{CH}_{3} \mathrm{NH}_{3} \mathrm{PbI}_{3}$ single crystals. Science 2015, 347, 967-970. [CrossRef] [PubMed]

8. Saliba, M.; Correa-Baena, J.-P.; Wolff, C.M.; Stolterfoht, M.; Phung, N.; Albrecht, S.; Neher, D.; Abate, A. How to make over 20\% efficient perovskite solar cells in regular (n-i-p) and inverted (p-i-n) architectures. Chem. Mater. 2018, 30, 4193-4201. [CrossRef]

9. Ionescu-Zanetti, C.; Mechler, A.; Carter, S.A.; Lal, R. Semiconductive Polymer Blends: Correlating Structure with Transport Properties at the Nanoscale. Adv. Mater. 2004, 16, 385-389. [CrossRef] 
10. Shin, S.S.; Lee, S.J.; Seok, S. Il Metal Oxide Charge Transport Layers for Efficient and Stable Perovskite Solar Cells. Adv. Funct. Mater. 2019, 29, 1900455. [CrossRef]

11. Liu, T.; Chen, K.; Hu, Q.; Zhu, R.; Gong, Q. Inverted Perovskite Solar Cells: Progresses and Perspectives. Adv. Energy Mater. 2016, 6, 1600457. [CrossRef]

12. Singh, R.; Singh, P.K.; Bhattacharya, B.; Rhee, H.-W. Review of current progress in inorganic hole-transport materials for perovskite solar cells. Appl. Mater. Today 2019, 14, 175-200. [CrossRef]

13. Cetin, C.; Chen, P.; Hao, M.; He, D.; Bai, Y.; Lyu, M.; Yun, J.-H.; Wang, L. Inorganic p-Type Semiconductors as Hole Conductor Building Blocks for Robust Perovskite Solar Cells. Adv. Sustain. Syst. 2018, 2, 1800032. [CrossRef]

14. Yin, X.; Guo, Y.; Xie, H.; Que, W.; Kong, L.B. Nickel Oxide as Efficient Hole Transport Materials for Perovskite Solar Cells. Sol. RRL 2019, 3, 1900001. [CrossRef]

15. Ma, F.; Zhao, Y.; Li, J.; Zhang, X.; Gu, H.; You, J. Nickel oxide for inverted structure perovskite solar cells. J. Energy Chem. 2020, 52, 393-411. [CrossRef]

16. Chen, W.; Wu, Y.; Tu, B.; Liu, F.; Djurišić, A.B.; He, Z. Inverted planar organic-inorganic hybrid perovskite solar cells with NiOx hole-transport layers as light-in window. Appl. Surf. Sci. 2018, 451, 325-332. [CrossRef]

17. Seo, Y.H.; Cho, I.H.; Na, S.I. Investigation of sol-gel and nanoparticle-based $\mathrm{NiO}_{\mathrm{x}}$ hole transporting layer for high-performance planar perovskite solar cells. J. Alloys Compd. 2019, 797, 1018-1024. [CrossRef]

18. Jin, Z.; Guo, Y.; Yuan, S.; Zhao, J.S.; Liang, X.M.; Qin, Y.; Zhang, J.P.; Ai, X.C. Modification of $\mathrm{NiO}_{\mathrm{x}}$ hole transport layer for acceleration of charge extraction in inverted perovskite solar cells. RSC Adv. 2020, 10, 12289-12296. [CrossRef]

19. Lian, X.; Chen, J.; Shan, S.; Wu, G.; Chen, H. Polymer Modification on the $\mathrm{NiO}_{\mathrm{x}}$ Hole Transport Layer Boosts Open-Circuit Voltage to $1.19 \mathrm{~V}$ for Perovskite Solar Cells. ACS Appl. Mater. Interfaces 2020, 12, 46340-46347. [CrossRef] [PubMed]

20. Najafi, M.; Di Giacomo, F.; Zhang, D.; Shanmugam, S.; Senes, A.; Verhees, W.; Hadipour, A.; Galagan, Y.; Aernouts, T.; Veenstra, S.; et al. Highly Efficient and Stable Flexible Perovskite Solar Cells with Metal Oxides Nanoparticle Charge Extraction Layers. Small 2018, 14, 1-10. [CrossRef] [PubMed]

21. Bretos, I.; Jiménez, R.; Ricote, J.; Calzada, M.L. Low-temperature crystallization of solution-derived metal oxide thin films assisted by chemical processes. Chem. Soc. Rev. 2018, 47, 291-308. [CrossRef] [PubMed]

22. Manders, J.R.; Tsang, S.-W.; Hartel, M.J.; Lai, T.-H.; Chen, S.; Amb, C.M.; Reynolds, J.R.; So, F. Solution-Processed Nickel Oxide Hole Transport Layers in High Efficiency Polymer Photovoltaic Cells. Adv. Funct. Mater. 2013, 23, 2993-3001. [CrossRef]

23. Chen, W.; Liu, F.-Z.; Feng, X.-Y.; Djurišić, A.B.; Chan, W.K.; He, Z.-B. Cesium Doped $\mathrm{NiO}_{\mathrm{x}}$ as an Efficient Hole Extraction Layer for Inverted Planar Perovskite Solar Cells. Adv. Energy Mater. 2017, 7, 1700722. [CrossRef]

24. Jung, J.W.; Chueh, C.C.; Jen, A.K.Y. A Low-Temperature, Solution-Processable, Cu-Doped Nickel Oxide Hole-Transporting Layer via the Combustion Method for High-Performance Thin-Film Perovskite Solar Cells. Adv. Mater. 2015, 27, 7874-7880. [CrossRef]

25. Merzhanov, A.G. The chemistry of self-propagating high-temperature synthesis. J. Mater. Chem. 2004, 14, 1779-1786. [CrossRef]

26. Deshpande, K.; Mukasyan, A.; Varma, A. Direct synthesis of iron oxide nanopowders by the combustion approach: Reaction mechanism and properties. Chem. Mater. 2004, 16, 4896-4904. [CrossRef]

27. Epifani, M.; Melissano, E.; Pace, G.; Schioppa, M. Precursors for the combustion synthesis of metal oxides from the sol-gel processing of metal complexes. J. Eur. Ceram. Soc. 2007, 27, 115-123. [CrossRef]

28. Bai, S.; Cao, M.; Jin, Y.; Dai, X.; Liang, X.; Ye, Z.; Li, M.; Cheng, J.; Xiao, X.; Wu, Z.; et al. Low-temperature combustionsynthesized nickel oxide thin films as hole-transport interlayers for solution-processed optoelectronic devices. Adv. Energy Mater. 2014, 4, 1301460. [CrossRef]

29. Liu, Z.; Chang, J.; Lin, Z.; Zhou, L.; Yang, Z.; Chen, D.; Zhang, C.; Liu, S. (Frank); Hao, Y. High-Performance Planar Perovskite Solar Cells Using Low Temperature, Solution-Combustion-Based Nickel Oxide Hole Transporting Layer with Efficiency Exceeding 20\%. Adv. Energy Mater. 2018, 8. [CrossRef]

30. Liu, Y.; Cai, H.; Su, J.; Ye, X.; Yang, J.; Liang, X.; Guan, J.; Zhou, X.; Yin, J.; Ni, J.; et al. Solution-combustion-based nickel oxide hole transport layers via fuel regulation in inverted planar perovskite solar cells. J. Mater. Sci. Mater. Electron. 2020, 31, 15225-15232. [CrossRef]

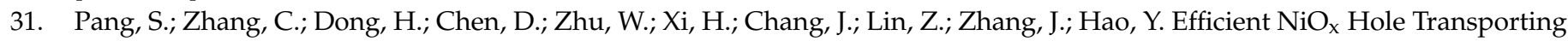
Layer Obtained by the Oxidation of Metal Nickel Film for Perovskite Solar Cells. ACS Appl. Energy Mater. 2019, 2, $4700-4707$. [CrossRef]

32. Wei, Y.; Yao, K.; Wang, X.; Jiang, Y.; Liu, X.; Zhou, N.; Li, F. Improving the efficiency and environmental stability of inverted planar perovskite solar cells via silver-doped nickel oxide hole-transporting layer. Appl. Surf. Sci. 2018, 427, 782-790. [CrossRef]

33. Hu, Z.; Chen, D.; Yang, P.; Yang, L.; Qin, L.; Huang, Y.; Zhao, X. Sol-gel-processed yttrium-doped NiO as hole transport layer in inverted perovskite solar cells for enhanced performance. Appl. Surf. Sci. 2018, 441, 258-264. [CrossRef]

34. Chen, P.C.; Yang, S.H. Potassium-Doped Nickel Oxide as the Hole Transport Layer for Efficient and Stable Inverted Perovskite Solar Cells. ACS Appl. Energy Mater. 2019, 2, 6705-6713. [CrossRef]

35. Lee, P.H.; Li, B.T.; Lee, C.F.; Huang, Z.H.; Huang, Y.C.; Su, W.F. High-efficiency perovskite solar cell using cobalt doped nickel oxide hole transport layer fabricated by NIR process. Sol. Energy Mater. Sol. Cells 2020, 208, 110352. [CrossRef]

36. Dewan, S.; Tomar, M.; Tandon, R.P.; Gupta, V. Zn doping induced conductivity transformation in NiO films for realization of p-n homo junction diode. J. Appl. Phys. 2017, 121, 215307. [CrossRef] 
37. Svanström, S.; Jacobsson, T.J.; Boschloo, G.; Johansson, E.M.J.; Rensmo, H.; Cappel, U.B. Degradation Mechanism of Silver Metal Deposited on Lead Halide Perovskites. ACS Appl. Mater. Interfaces 2020, 12, 7212-7221. [CrossRef]

38. Ponmudi, T.S.; Lee, C.-W.; Lai, C.-C.; Tsai, C.-H. Comparative study on the effect of annealing temperature on sol-gel-derived nickel oxide thin film as hole transport layers for inverted perovskite solar cells. J. Mater. Sci. Mater. Electron. 2021, 1-10. [CrossRef]

39. Lin, Y.R.; Liao, Y.S.; Hsiao, H.T.; Chen, C.P. Two-step annealing of $\mathrm{NiO}_{\mathrm{x}}$ enhances the $\mathrm{NiO}_{\mathrm{x}}-$ perovskite interface for highperformance ambient-stable p-i-n perovskite solar cells. Appl. Surf. Sci. 2020, 504, 144478. [CrossRef]

40. Nandy, S.; Saha, B.; Mitra, M.K.; Chattopadhyay, K.K. Effect of oxygen partial pressure on the electrical and optical properties of highly (200) oriented p-type $\mathrm{Ni}_{1-\mathrm{x}} \mathrm{O}$ films by DC sputtering. J. Mater. Sci. 2007, 42, 5766-5772. [CrossRef]

41. Wan, X.; Jiang, Y.; Qiu, Z.; Zhang, H.; Zhu, X.; Sikandar, I.; Liu, X.; Chen, X.; Cao, B. Zinc as a New Dopant for NiOx-Based Planar Perovskite Solar Cells with Stable Efficiency near 20\%. ACS Appl. Energy Mater. 2018, 1, 3947-3954. [CrossRef]

42. Mahmud, M.A.; Elumalai, N.K.; Upama, M.B.; Wang, D.; Chan, K.H.; Wright, M.; Xu, C.; Haque, F.; Uddin, A. Low temperature processed $\mathrm{ZnO}$ thin film as electron transport layer for efficient perovskite solar cells. Sol. Energy Mater. Sol. Cells 2017, 159, 251-264. [CrossRef]

43. Lee, J.H.; Noh, Y.W.; Jin, I.S.; Jung, J.W. Efficient planar heterojunction perovskite solar cells employing a solution-processed Zn-doped $\mathrm{NiO}_{x}$ hole transport layer. Electrochim. Acta 2018, 284, 253-259. [CrossRef]

44. Tauc, J. Optical properties and electronic structure of amorphous Ge and Si. Mater. Res. Bull. 1968, 3, 37-46. [CrossRef]

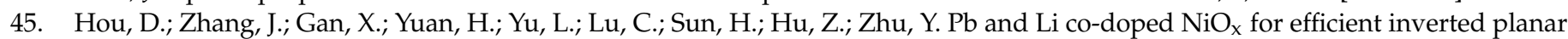
perovskite solar cells. J. Colloid Interface Sci. 2020, 559, 29-38. [CrossRef] [PubMed]

46. Wu, Y.; Yang, X.; Chen, W.; Yue, Y.; Cai, M.; Xie, F.; Bi, E.; Islam, A.; Han, L. Perovskite solar cells with 18.21\% efficiency and area over $1 \mathrm{~cm}^{2}$ fabricated by heterojunction engineering. Nat. Energy 2016, 1, 1-7. [CrossRef]

47. García-Rodríguez, R.; Ferdani, D.; Pering, S.; Baker, P.J.; Cameron, P.J. Influence of bromide content on iodide migration in inverted $\mathrm{MAPb}\left(\mathrm{I}_{1-X} \mathrm{Br}_{\mathrm{x}}\right)_{3}$ perovskite solar cells. J. Mater. Chem. A 2019, 7, 22604-22614. [CrossRef]

48. Liu, D.; Li, Y.; Yuan, J.; Hong, Q.; Shi, G.; Yuan, D.; Wei, J.; Huang, C.; Tang, J.; Fung, M.K. Improved performance of inverted planar perovskite solar cells with F4-TCNQ doped PEDOT:PSS hole transport layers. J. Mater. Chem. A 2017, 5, 5701-5708. [CrossRef]

49. Tsai, C.H.; Lin, C.M.; Kuei, C.H. Improving the performance of perovskite solar cells by adding 1,8-diiodooctane in the $\mathrm{CH}_{3} \mathrm{NH}_{3} \mathrm{PbI}_{3}$ perovskite layer. Sol. Energy 2018, 176, 178-185. [CrossRef] 